\title{
The prevalence of renal impairment in the elderly hospitalized population
}

This article was published in the following Dove Press journal:

International Journal of General Medicine

3 June 2009

Number of times this article has been viewed

\author{
Maneshveri Pather \\ Formerly of the Department \\ of Medicine, Clayponds Hospital, \\ London, UK
}

Correspondence: Maneshveri Pather I0I-2828 Cruickshank St, Abbotsford, British Columbia,V2T5M4, Canada Fax + I 604853 |34|

Email manesh2@doctors.org.uk

\begin{abstract}
Renal impairment has already been cited as being under-reported. A retrospective cross-sectional study was carried out. The sample population consisted of 94 inpatients aged over 60 years at Clayponds Hospital in the UK who had been admitted for rehabilitation from acute hospitals. The glomerular filtration rate (GFR) was calculated using the Cockcroft-Gault formula modified for SI units. Renal impairment was found in 95.7\% (95\% CI: 91.8-99.6) of the sample (GFR $<90 \mathrm{ml} / \mathrm{min}$ ). The study confirms that undetected renal impairment is prevalent. What is significant is that all of the subjects in this study were admitted from acute hospitals to Clayponds Hospital for rehabilitation. It is recommended that more attention be paid to the identification of patients with renal failure in hospitals owing to its significant morbidity and mortality.
\end{abstract}

Keywords: renal impairment, GFR, elderly

\section{Introduction}

Underdiagnosis of renal impairment has been reported. ${ }^{1}$ Diagnosis of renal impairment may be missed because of the inadequacy of screening. Progression to end-stage renal failure may be slowed when detected at an early stage. ${ }^{2}$ Chronic renal failure places a huge burden on health resources because dialysis or transplantation is necessary to prevent death. ${ }^{3}$ In addition, renal impairment is associated with increased cardiovascular risk. ${ }^{4}$ Complications may be minimized with effective detection and treatment. The estimated life-time risk and decrease in life expectancy associated with end-stage renal failure is comparable with that of colorectal cancer, breast cancer, and prostatic cancer. ${ }^{1}$ The purpose of this study was to establish the prevalence of undiagnosed renal impairment in the hospitalized elderly population.

\section{Method}

In order to assess the prevalence of undiagnosed renal impairment in the elderly hospitalized population, a retrospective cross-sectional study was carried out. The study population comprised 94 inpatients $(n=94)$ admitted to Clayponds Hospital for general rehabilitation between February and May 2005 from other acute hospitals. The patients comprised 69 women and 25 men all aged over 60 years. Medical and laboratory records for each subject were viewed, which included serum creatinine levels and the weight of each patient. The glomerular filtration rate (GFR; $\mathrm{mL} / \mathrm{min}$ ) for each patient was calculated using the modified Cockcroft-Gault formula: ${ }^{5}$ GFR in males can be obtained from the following equation, (140-age) * weight $(\mathrm{kg}) / 814$ 


\section{GFR distribution}

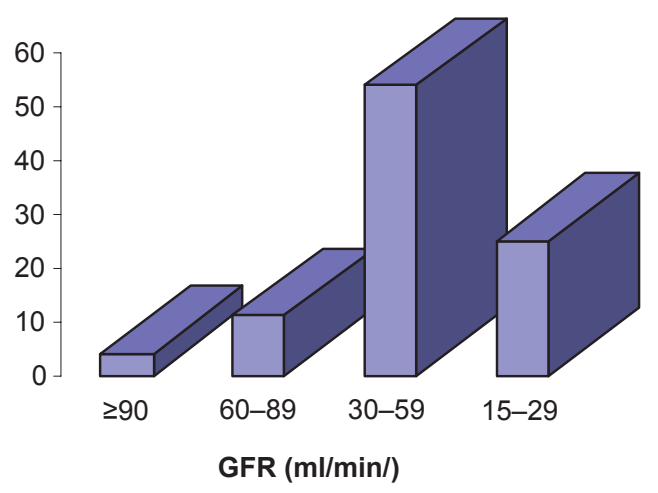

$\square$ No. of patients

Figure I Glomerular filtration rate (GFR) distribution.

* creatinine $(\mathrm{mmol} / \mathrm{l})$ and in females, $0.85 *(140$-age $) *$ weight $(\mathrm{kg}) / 814 *$ creatinine $(\mathrm{mmol} / \mathrm{l})$. This was adjusted for International System of Units (SI) units.

Patients admitted from acute hospitals to Clayponds Hospital for rehabilitation were included in the study irrespective of diagnosis. Patients admitted to Clayponds Hospital from home for the management of acute pathology were excluded owing to a greater likelihood of renal impairment being present in this population. A total of 119 patients were admitted to Clayponds Hospital between February 2005 and May 2005, however, 21 had to be excluded owing to the following factors: age under 60 years, a pre-existing diagnosis of renal failure, no weight documented during admission, no serum creatinine checked during admission stay, or admission from home for the management of acute pathologies. It was not the purpose of this study to examine confounding factors or co-morbidities.

\section{Results}

The degree of renal impairment was categorized based on the GFR as follows: no renal impairment, GFR $\geq 90 \mathrm{~mL} / \mathrm{min}$; mild impairment, GFR 60-89 $\mathrm{mL} / \mathrm{min}$; moderate renal impairment, GFR 30-59 mL/min; and severe renal impairment, GFR 15-29 mL/min. ${ }^{6}$

As shown in Figure 1, 25 patients (26.6\%, 95\% confidence interval [CI]: 7.6-30.6) had mild renal impairment, 54 (57.4\% , 95\% CI: 47-67) had moderate renal impairment, 11 (11.7\%, 95\% CI: 5.2-18.2) had severe impairment, and only four (4.3\%, 95\% CI: $0.3-8)$ had normal renal function (Figure 1). The mean total GFR was $44.5 \pm 20.9 \mathrm{~mL} / \mathrm{min}$.

\section{Discussion}

This study has shown that renal impairment in the UK hospitalized elderly population is underdiagnosed.
Most elderly patients entering UK hospitals for acute pathology have a serum creatinine and weight measurement taken during admission, but identification of renal impairment is mostly missed. The vast majority of subjects in this study (95.7\%) had renal impairment as defined by GFR. More than $50 \%$ had a moderate impairment of renal function. This is significant as renal failure has major health implications as has already been stated. The study was limited by its small sample size and lack of randomization. However, it validates the fact that chronic renal disease is prevalent and underdiagnosed. It is recommended that hospitalized elderly patients with renal impairment be identified and managed appropriately. The implementation of this will require further work.

\section{Disclosure}

The author reports no conflicts of interest in this work.

\section{References}

1. McClellan WM, Ramirez SP, Jurkovitz C. Screening for chronic kidney disease: unresolved issues. J Am Soc Nephrol. 2003;14:581-587.

2. Chadban SJ, Briganti EM, Kerr PG, et al. Prevalence of kidney damage in Australian adults: The AusDiab kidney study. $J$ Am Soc Nephrol. 2003; 14:5131-5138.

3. Cas A. Kidney disease: Are you at risk? Screening of selected patients for proteinuria could help reduce the incidence of ESRD. MJA. $2002 ; 178$.

4. Rostand SG, Brunzell JD, Cannon RO 3rd, Victor RG. Cardiovascular complications in renal failure. J Am Soc Nephrol. 1991;2(6):1053-1062.

5. Cockcroft DW, Gault MH. Prediction of creatinine clearance from serum creatinine. Nephron. 1976;16:31-41.

6. Roderick PJ, Feest T. Assessment of the patient with renal disease: The epidemiology of renal disease. In: Davison AM, Cameron JS, Grunfeld JP, et al. editors. Oxford Textbook of Clinical Nephrology, 3rd edition. Oxford: Oxford University Press; 2005.

7. Li PK, Kwan BC, Leung CB, et al; For The Hong Kong Society Of Nephrology. Prevalence of silent kidney disease in Hong Kong: The Screening of Hong Kong Asymptomatic Renal population and Evaluation (SHARE) program. Kidney Int. 2005;67:S36-S40. 
8. Viktorsdottir O, Palsson R, Andresdottir MB, Aspelund T, Gudnason V, Indridason OS. Prevalence of chronic kidney disease based on estimated glomerular filtration rate and proteinuria in Icelandic adults. Nephrol Dial Transplant. 2005;20(9):1799-1807.

9. Go AS, Chertow GM, Fan D, McCulloch CE, Hsu CY. Chronic kidney disease and the risk of death, cardiovascular events, and hospitalization. N Engl J Med. 2004;351:1296-1305.
10. Weiner DE, Tighiouart H, Stark PC, et al. Kidney disease as a risk factor for recurrent cardiovascular disease and mortality. Am J Kidney Dis. 2004;44(2):198-206.

International Journal of General Medicine

\section{Publish your work in this journal}

The International Journal of General Medicine is an international, peer-reviewed open-access journal that focuses on general and internal medicine, pathogenesis, epidemiology, diagnosis, monitoring and treatment protocols. The journal is characterized by the rapid reporting of reviews, original research and clinical studies across all disease areas.
A key focus is the elucidation of disease processes and management protocols resulting in improved outcomes for the patient.The manuscript management system is completely online and includes a very quick and fair peer-review system. Visit http://www.dovepress.com/ testimonials.php to read real quotes from published authors.

Submit your manuscript here: http://www.dovepress.com/international-journal-of-general-medicine-journal 